\title{
EHMTI-0146. Topiramate in migraine prevention
}

\author{
S Ristic ${ }^{1 *}, \mathrm{D}$ Ristic $^{2}$ \\ From 4th European Headache and Migraine Trust International Congress: EHMTIC 2014 \\ Copenhagen, Denmark. 18-21 September 2014
}

\section{Purpose}

The present analysis of pooled data from those 3 trials was performed to characterize the efficacy and adverse events of topiramate for migraine prevention in subjects who had used other migraine preventive medications.

\section{Metods}

We were analyzed patients with migraine, who had used migraine preventive medications, within approximately 8 months period.Patients were admitted to the Department of Neurology in Nis, after observing their miagraine atack, during the period from January-December 2013.All of the patients have been diagnostically examend by:interictal EEG, head CT, MRI,MRA angiography. We analyzed monthly migraine frequency from baseline period to endpoint. We compared different dosage of topiramate, so as the presence od adverse events. We started with $25 \mathrm{mg} /$ day od topiramate and this lasted for 7 days and we incresed dosage of topiramate $25 \mathrm{mg} /$ week. Maximum dosage was $200 \mathrm{mg} /$ day.

\section{Results}

Of sum of 167 patients, 96 (57,48\%)female, aged between 21-59 years (mean age 39,2 ) were recruited. Subjects were treated with topiramate 50,100 or $200 \mathrm{mg} /$ day). More subjects on topiramate $50 \mathrm{mg}$./day (41\%), $100 \mathrm{mg}$./day (63\%) and $200 \mathrm{mg}$./day (54\%) exhibited $\geq 50 \%$ reductions in monthly migraine frequency. Most common adverse event was paresthesis, incidence was $11 \%$, fatigue $3 \%$, nausea $2 \%$. Mean duration of paresthesia was 19 days. Cognitive sympthoms was registered only in 2 patients.

\section{Conclusion}

In subjects who had previously taken other migraine preventives, treatment with topiramate $100 \mathrm{mg} /$ day and $200 \mathrm{mg} /$ day significantly reduced mean monthly migraine frequency. In our study, the lower dose of

${ }^{1}$ Department of Neurology, Epilepsy Unit, Nis, Serbia

Full list of author information is available at the end of the article topiramate exhibited similar efficacy. Adverse events is rarely and most frequent is paresthesia which disappeares in 3 weeks.

No conflict of interest.

\section{Authors' details}

${ }^{1}$ Department of Neurology, Epilepsy Unit, Nis, Serbia. ${ }^{2}$ Institutae of

Pulmonary Disaeses, Institutae of Pulmonary Disaeses, Nis, Serbia.

Published: 18 September 2014

doi:10.1186/1129-2377-15-S1-G32

Cite this article as: Ristic and Ristic: EHMTI-0146. Topiramate in migraine

prevention. The Journal of Headache and Pain 2014 15(Suppl 1):G32.

\section{SpringerOpen ${ }^{\odot}$}

(c) 2014 Ristic and Ristic; licensee Springer. This is an Open Access article distributed under the terms of the Creative Commons Attribution License (http://creativecommons.org/licenses/by/2.0), which permits unrestricted use, distribution, and reproduction in any medium, provided the original work is properly cited.
Submit your manuscript to a SpringerOpen ${ }^{\circ}$ journal and benefit from:

- Convenient online submission

- Rigorous peer review

- Immediate publication on acceptance

- Open access: articles freely available online

- High visibility within the field

- Retaining the copyright to your article

Submit your next manuscript at $>$ springeropen.com 